\title{
Particularități ale capilaroscopiei periunghiale la copii - date din literatura de specialitate
}

\author{
Sigrid Covaci ${ }^{1,2}$, Oana-Maria Farkas ${ }^{3}$, Alexis-Virgil Cochino ${ }^{1,3}$ \\ ${ }^{1}$ Universitatea de Medicină şi Farmacie „Carol Davila“, Bucureşti, România \\ ${ }^{2}$ Spitalul Universitar "Sf. Maria“, Bucureşti, România \\ ${ }^{3}$ Institutul Naţional pentru Sănătatea Mamei şi Copilului „Alessandrescu-Rusescu“, Bucureşti, România
}

\begin{abstract}
REZUMAT
Capilaroscopia periunghială este o metodă imagistică uşor de efectuat, neinvazivă şi ieftină, extrem de importantă în evaluarea adulţilor şi copiilor cu suspiciune sau diagnostic de boală de ţesut conjunctiv. Modificările microvascularizaţiei periferice detectate la examinarea capilaroscopică pot oferi informaţii utile pentru diagnosticul diferenţial şi monitorizarea terapiei în majoritatea bolilor ţesutului conjunctiv. Deşi în reumatologia adultului această metodă s-a bucurat de un interes crescut în ultimele decenii, studiile la copii şi adolescenţi sunt mai puţine şi, în general, datele capilaroscopice utilizate la copii sunt extrapolate de la adulţi. Aspectul capilaroscopic normal la copil prezintă unele diferenţe care trebuie să fie cunoscute atunci când se efectuează capilaroscopie periunghială.
\end{abstract}

Cuvinte cheie: copil, capilaroscopie periunghială, boli de ţesut conjunctiv

\section{INTRODUCERE}

Capilaroscopia periunghială (CPU) este o metodă imagistică neinvazivă şi extrem de valoroasă, utilizată pentru studiul microcirculaţiei periferice $(1,2,3,4)$. Această metodă are aplicaţii clinice în evaluarea adulţilor, precum şi a copiilor cu suspiciune sau diagnostic de bolă de ţesut conjunctiv (BŢC) $(5,6,7,8,9,10,11,12,13)$.

La adulţi, principala indicaţie pentru CPU este fenomenul Raynaud, dar la copii această afecţiune este rară şi indicaţiile principale sunt reprezentate de scleroza sistemică juvenilă $(\mathrm{ScSj})$ şi dermatomiozita juvenilă (DMJ) $(14,15,16,17,18,19,20,21)$.

Indiferent de vârstă, adulţi sau copii, în timpul examinării CPU, se observă şi se documentează următoarele aspecte: transparenţa pielii - plexul venos subpapilar; distribuţia, densitatea, dimensiunile (lăţime şi lungime) şi forma capilarelor (forma tipică de ac de păr, tortuoase, ramificate, dilatate sau gigante); prezenţa hemoragiilor sau edemului şi uneori fluxul sangvin capilar $(22,23,24)$.
Atât la copii, cât şi la adulţi, aspectul capilaroscopic normal este reprezentat printr-o dispunere paralelă şi regulată a rândului distal de capilare, capilare cu forma unui ac de păr deschis sau a literei U inversate, cu un braţ mai subţire reprezentând ramura arterială şi un braţ mai gros reprezentând ramura venoasă şi o densitate de 7-17 pe milimetru, cu o medie de 9 capilare pe milimetru $(6,7,9$, 12,15,22,23,24).

Principalele diferenţe în ceea ce priveşte aspectul capilarosocopic normal la copii sunt reprezentate de o vizibilitate mai mare a plexului venos subpapilar, un număr mai mic de anse capilare pe milimetru şi o frecvenţă mai mare a anselor capilare atipice $(10,12,13,24,25)$.

\section{Parametrii capilaroscopici}

Plexul venos subapapilar este vizibil la naştere şi devine progresiv invizibil cu vârsta, astfel încât copiii au o vizibilitate mai mare a plexului venos subpapilar, comparativ cu adulţii $(22,24)$. Odată cu 
îmbătrânirea, pielea devine mai transparentă şi plexul venos subpapilar poate deveni din nou vizibil.

Distribuţia capilară este un parametru capilaroscopic util în practica clinică reumatologică. La indivizii sănătoşi, copii sau adulţi, ansele capilare au o distribuţie omogenă, paralelă şi ordonată de-a lungul patului unghial, cu distanţe egale între ramurile ascendente şi descendente ale capilarelor $(6,12,23,24,25,26)$.

Densitatea capilară este definită ca numărul de capilare pe un milimetru în rândul distal de capilare al fiecărui deget şi este unul dintre cei mai importanţi parametri pentru diagnosticarea precoce a persoanelor cu risc pentru a dezvolta o BȚC $(2,7,23)$. Mai multe studii au arătat că densitatea capilară este direct influenţată de vârstă, copiii mai mici având mai puţine capilare în comparaţie cu copiii mai mari şi adulţi $(12,27)$. Intr-un studiu efectuat la 70 de copii (dintre care 17 copii sănătoşi) şi 20 adulţi sănătoşi, densitatea liniară capilară a fost semnificativ mai mare la adulţii sănătoşi comparativ cu copiii sănătoşi (cu o medie de 6,9 capilare/ mm) (12). Această tendinţă de creştere a densităţii capilare cu vârsta a fost raportată de mulţi autori ca parte a procesului de maturare $(12,28)$. Având în vedere aceste diferenţe, unii autori au dezvoltat un sistem de notare a densităţii capilare, în care au introdus vârsta ca parametru eficient pentru cuantificarea numărului de capilare (27).

Reducerea densităţii capilare este definită atunci când există mai puţin de 30 de capilare pe $5 \mathrm{~mm}$ iar zona avasculară este definită ca lipsa a două sau mai multe capilare consecutive (6). Sistemele de notare utilizate pentru cuantificarea zonelor avasculare sunt aceleaşi pentru copii şi pentru adulţi.

Măsurarea dimensiunilor capilare include mai mulţi parametrii, dar în practica clinică curentă, de obicei se investighează lăţimea capilară şi lungimea capilară. Nu există un consens cu privire la lăţimea capilară, în literatură fiind raportate diferite valori. Dolezoleva şi colab. au raportat o lăţime medie a capilarelor de $47 \mu \mathrm{m}$ la copii sănătoşi şi 40 $\mu \mathrm{m}$ la adulţi sănătoşi, concluzionând că lăţimea capilară este influenţată de vârstă, adulţii şi copii mai mari având capilare mai înguste comparativ cu copiii mai mici (12). La adulţi, diametrul braţului arterial capilar mai mare de $15 \mu \mathrm{m}$ sau cel al braţului venos mai mare de $20 \mu \mathrm{m}$ defineşte capilarul dilatat $(1,7,23,29)$. Capilarele cu dilatare omogenă (atât pe braţul arterial cât şi pe cel venos ) având o formă caracteristică de potcoavă şi un diametru transvers mai mare de $100 \mu \mathrm{m}$ definesc capilarele gigante
(23). Capilarele alungite sunt definite ca anse capilare mai lungi de $300 \mu \mathrm{m}(0,300 \mathrm{~mm})$ (30). În practica clinică curentă, evaluările calitative ale dimensiunilor capilare sunt considerate satisfăcătoare, în timp ce evaluările semi-cantitative îşi găsesc utilitatea în special în studiile clinice.

Unii autori au raportat că 15-34\% dintre adulţii sănătoşi au capilare anormale, cum ar fi anse capilare şerpuite, tortuoase, ectazii sau cu alte forme bizare $(30,31)$. În cea mai mare serie pediatrică, prezenţa capilarelor stufoase a fost raportată la $6 \%$ dintre copiii sănătoşi iar prezenţa capilarelor cu forme bizare la $27 \%$ dintre copiii sănătoşi, autorii studiului considerând aceste modificări drept o caracteristică distinctă a reţelei capilare la copii (25). Aparent copiii de vârstă preşcolară au mai multe capilare largi, cu mai multe tortuozităţi, cu forme bizare şi distribuţie uniformă, comparativ cu adulţii (12).

\section{Aspecte capilaroscopice în bolile reumatice}

Dintre toate bolile de ţesut conjunctiv, scleroza sistemică $(\mathrm{ScS})$ prezintă modelul capilaroscopic cel mai specific iar CPU este o investigaţie cheie pentru diagnosticul acestei afecţiuni $(1,8,15)$. În funcţie de gradul şi stadiul microangiopatiei din $\mathrm{ScS}$, modelul capilaroscopic sclerodermic poate fi caracterizat de prezenţa capilarelor dilatate/ gigante, scăderea densităţii capilare/zone avasculare, hemoragii şi neo-angiogeneză $(1,4,32)$. Anomaliile capilaroscopice observate în $\mathrm{ScS}$ la copii sunt aceleaşi cu cele de la adulţi $(9,10,34,35)$. Mai multe studii au raportat prezenţa simultană a capilarelor gigante şi a zonelor avasculare la $>60 \%$ dintre copiii cu ScSj $(10,34,35)$. S-a raportat că majoritatea copiilor cu anomalii capilare nespecifice la momentul diagnosticului $\mathrm{ScSj}$, dezvoltă un model capilaroscopic sclerodermic în cursul bolii. (34).

Aproximativ 60\% dintre pacienţii cu DMJ prezintă un model capilaroscopic sclerodermic $(10,11,35,36)$. În DMJ, la examinarea CPU se constată mai multe capilare ramificate comparativ cu $\operatorname{ScSj}(35,36,37)$.

Deşi s-au raportat variete modificări ale anselor capilarelor la 40-90\% dintre pacienţii cu lupus eritematos sistemic cu debut juvenil sau la vârsta adultă, nu a fost descris nici un model capilaroscopic specific acestei afecţiuni $(9,10,12,38)$.

Modificările capilaroscopice pot fi observate şi în alte boli reumatismale pediatrice, dar sunt mai puţin frapante decât cele observate în $\mathrm{ScSj}$ şi DMJ. 


\section{CONCLUZII}

Aspectul capilaroscopic normal la copii este similar cu cel descris la adulţi, diferenţele fiind reprezentate de un număr mai mic de anse capilare pe milimetru, capilare mai largi la copiii mici, o vizibilitate mai mare a plexului venos subpapilar şi o frecvenţă mai mare a anselor capilare atipice. Aceste diferenţe trebuie cunoscute şi luate în considera-

\section{BIBLIOGRAFIE}

1. Cutolo M, Sulli A, Pizzorni C, Accardo S. Nailfold videocapillaroscopy assessment of microvascular damage in systemic sclerosis. J Rheumatol 2000; 27: 155-60.

2. Ingegnoli $F$, Gualtierotti R, Lubatti $C$ et al. Feasibility of different capillaroscopic measures for identifying nailfold microvascular alterations. Seminars in Arthritis \& Rheumatism. 2009;38(4):289-295.

3. Le JH, Cho Kl. Association between endothelial function and microvascular changes in patients with secondary Raynaud's phenomenon. Clinical Rheumatology. 2014;33(11):1627-1633

4. Maricq HR, Harper FE, Khan MM, Tan EM, LeRoy EC. Microvascular abnormalities as possible predictors of disease subsets in Raynaud phenomenon and early connective tissue disease. Clin Exp Rheumatol. 1983;1(3):195-205.

5. Maricq HR, LeRoy EC. Patterns of finger capillary abnormalities in connective tissue disease by "wide-field" microscopy. Arthritis Rheum 1973; 16: 619-28.

6. Bollinger A, Fagrell B, Clinical capillaroscopy - a guide to its use in clinical research and practice. Hogrefe \& Huber Publishers Toronto 1990: pp. 1-123

7. Cutolo M, Pizzorni C, Sulli A. Capillaroscopy. Best Pract Res Clin Rheumatol. 2005; 19( 3): 437-52.

8. Cutolo M, Sulli A, Secchi ME, Olivieri M, Pizzorni C. The contribution of capillaroscopy to the differential diagnosis of connective autoimmune diseases. Best Pract Res Clin Rheumatol. 2007;21(6): 1093-108.

9. Ingegnoli F, Herrick AL (2013). Nailfold Capillaroscopy in Pediatrics. Arthritis Care \& Research, 65: 1393-1400. doi:10.1002/acr.22026

10. Spencer Green G, Schlesinger M, Bove KE, Levinson JE, Schaller JG, Hanson V et al. Nailfold capillary abnormalities in childhood rheumatic diseases. J Pediatr 1983;102:341-6.

11. Carpentier $P$, Jeannoel $P$, Bost M, Franco A. Peri-ungual capillaroscopy in pediatric practice. Pediatrie 1988;43(2):165-9.

12. Dolezalova P, Young SP, Bacon PA, Southwood TR. Nailfold capillary microscopy in healthy children and in childhood rheumatic diseases: a prospective single blind observational study. Annals of the Rheumatic Diseases. 2003;62(5):444-449. doi: 10.1136/ard.62.5.444.

13. Piotto DG, Len CA, Hilario MO, Terreri MT. Nailfold capillaroscopy in children and adolescents with rheumatic diseases. Rev Bras Reumatol. 2012;52:722-32.

14. Cutolo M, Grassi W, Matucci Cerinic M. Raynaud's phenomenon and the role of capillaroscopy. Arthritis Rheum. 2003;48(11):3023-30

15. Cutolo M, Pizzorni C, Tuccio M et al. Nailfold videocapillaroscopy patterns and serum autoantibodies in systemic sclerosis, Rheumatol 2004, 43: 719-726

16. Belch JJF. Raynaud'phenomenon: its relevance to scleroderma. Ann Rheum Dis. 1991;50:839-45.

17. Block JA, Sequeira W. Raynaud's phenomenon. Seminar Lancet, 357, 2001, 2042-8.

18. Krieger I, Brough AJ. Raynaud's phenomenon in an infant. J Pediatr. 1972;80:145-51.

19. Herrick AL, Jayson MI. Primary Raynaud's phenomenon in early childhood. Br J Rheumatol. 1991;30:223-5.

20. Guntheroth WG, Morgan BC, Harbinson JA, Mullins GL. Raynaud's disease in children. Circulation. 1967;36:724-9. re în evaluarea copiilor cu boli reumatismale, în special cu BȚC. Modelele capilaroscopice tipice descrise în BŢC sunt similare la populaţia adultă şi cea pediatrică.

CPU este o examinare fezabilă la copii, deoarece este o metodă simplă, neinvazivă, ieftină, uşor de efectuat şi uşor de repetat, fiind de asemenea cea mai bună metodă pentru evaluarea microangiopatiei.

Conflict of interest: none declared Financial support: none declared

21. Nigrovic PA, Fuhlbrigge RC, Sundel RP. Raynaud's phenomenon in children: A retrospective review of 123 patients. Pediatrics. 2003;111:715-21.

22. Etehad Tavakol M, Fatemi A, Karbalaie A, Emrani Z, Erlandsson BE. Nailfold Capillaroscopy in Rheumatic Diseases: Which Parameters Should Be Evaluated? Biomed Res Int. 2015;2015:974530.

23. Cutolo M., Sulli A., Smith V. How to perform and interpret capillaroscopy. Best Practice and Research: Clinical Rheumatology. 2013 Apr; 27(2):237-248.

24. Allen J. Capillaroscopy in Healthy Subjects of Different Ages. In: Cutolo M, editor. Atlas of Capillaroscopy in Rheumatic Diseases. Milan: Elsevier; 2010. pp. 49-53.

25. Terreri MT, Andrade LE, Puccinelli ML, Hilário MO, Goldenberg J. Nail fold capillaroscopy: Normal findings in children and adolescents. Semin Arthritis Rheum. 1999 Aug;29(1):36-42

26. Kamińska-Winciorek A., Deja G., Polańska J., Jarosz-Chobot P. Diabetic microangiopathy in capillaroscopic examination of juveniles with diabetes type 1. Postępy Higieny i Medycyny Doświadczalnej. 2012; 66:51-59.

27. Hoerth C., Kundi M., Katzenschlager R., Hirschl M. Qualitative and quantitative assessment of nailfold capillaries by capillaroscopy in healthy volunteers. Vasa. 2012;41(1):19-26. doi: 10.1024/0301-1526/ a000159.

28. Herrick AL, Moore T, Hollis S, Jayson MIV. The influence of age on nailfold capillary dimensions in childhood. J Rheumatol. 2000; 27:797-800.

29. Herrick AL, Clark S. Quantifying digital vascular disease in patients with primary Raynaud's phenomenon and systemic sclerosis. Ann Reum Dis. 57, 1998, 70-78

30. Kabasakal Y, Elvins DM, Ring EFJ, McHugh NJ. Quantitative nailfold capillaroscopy findings in a population with connective tissue disease and in normal healthy controls. Ann Rheum Dis 1996;55:507-12.

31. Andrade LEC, Gabriel A Jr, Assad RL, Ferrari AJL, Atra E. Panoramic nailfold capillaroscopy: A new reading method and normal range. Semin Arthritis Rheum 1990;20:21-31.

32. Maricq HR, Widefield capillary microscopy. Technique and rating scale for abnormalities seen in scleroderma and related disorders, Arthr Rheum 1981, 24: 1159-1165

33. Martini G, Foeldvari I, Russo R, Cuttica R, Eberhard A, Ravelli A et al. Systemic sclerosis in childhood: clinical and immunologic features of 153 patients in an international database. Arthritis Rheum 2006; 54:3971-8.

34. Russo R, Katsicas M. Clinical characteristics of children with juvenile systemic sclerosis: Follow up of 23 patients in a single tertiary center. Pediatr Rheumatol 2007;5:1-9.

35. Nussbaum Al, Silver RM, Maricq HR. Serial changes in nailfold capillary morphology in childhood dermatomyositis. Arthritis Rheum. 1983; 26:1169-72.

36. Silver RM, Maricq HR. Childhood dermatomyositis: serial microvascular studies. Pediatrics. 1989;83:278-83.

37. Smith RL, Sundberg J, Shamiyah E, Dyer A, Pachman LM. Skin involvement in juvenile dermatomyositis is associated with loss of end row nailfold capillary loops. J Rheumatol 2004;31(8):1644-9.

38. Redisch W, Messina EJ, Hughes G, McEwen C. Capillaroscopic observations in rheumatic diseases. Ann Rheum Dis. 1970;29:244-53 